\title{
NOTES
}

\section{IMPLIED PRIVATE RIGHTS OF ACTION UNDER THE UNITED STATES HOUSING ACT OF 1937}

In the United States Housing Act of 1937 (USHA), ${ }^{1}$ Congress enacted sweeping legislation designed to correct one of the fundamental socio-economic ills of the Great Depression: "the acute shortage of decent, safe, and sanitary dwellings for families of lower income."2 The "shortage" persisted in the postwar era, and the USHA program today remains a central institutional feature of the federal public housing niachinery.

The prograni's main function is to subsidize the operation of local public housing authorities. ${ }^{3}$ The Department of Housing and Urban Development (HUD) and a local housing authority enter into an Annual Contributions Contract, under which HUD guarantees the payment of specified subsidies and the local agency pledges satisfaction of multiple departniental conditions of subsidization. ${ }^{4}$ Local housing authorities can qualify for federal assistance only by complying with the provisions of federal housing law and HUD regnlations, ${ }^{5}$ including, for exaniple, the limitations on the rent that may be charged to tenants ${ }^{6}$ and the extensive requirements for the inclusion of specific protective provisions in leases between housing authorities and tenants. ${ }^{7}$

1. 42 U.S.C.A. $\S \S 1437-1437$ r (West 1978 \& Supp. 1987).

2. 42 U.S.C. $\$ 1437$ (1982). The broad policy goals of the USHA are set out as follows: It is the policy of the United States to promote the general welfare of the Nation by employing its funds and credit ... to assist the several States and their political subdivisions to remedy the unsafe and unsanitary housing conditions and the acute shortage of decent, safe, and sanitary dwellings for families of lower income and . . . to vest in local public housing agencies the maximum amount of responsibility in the administration of their Id. housing programs.

3. 42 U.S.C. $\$ \S 1437,1437 \mathrm{c}(\mathrm{a})(1982)$.

4. 42 U.S.C. $\S \S 1437 c-1437 d$ (1982 \& Supp. III 1985).

5. See, e.g., Beckham v. New York City Hous. Auth., 755 F.2d 1074, 1075-76 (2d Cir. 1985) ("[S]ubsidies are conditioned on annual verification ... of each public housing tenant and the Authority's compliance with [both] the federal Housing Act and the regulations governing the federally-funded public housing program.").

6. 42 U.S.C. $\S 1437 a$ (1982 \& Supp. III 1985) (the "Brooke Amendment").

7. 24 C.F.R. $\$ 966.4$ (1987). 
In recent years, tenants of federally subsidized public housing have begun to seek redress of their grievances against local housing authorities or HUD by bringing private actions in federal courts based on various provisions of the USHA or related HUD regulations. Because the USHA does not itself expressly provide for a private right of action to enforce its provisions, these cases present a threshold question: Is there an implied private right of action under the United States Housing Act of $1937 ?^{8}$

This note begins with an overview of the development and current status of implied right of action doctrine. ${ }^{9}$ It then turns to a survey of the lower federal courts' conflicting and often confused analysis of the USHA implied right of action issue. ${ }^{10}$ The note then seeks to clarify the issue through an analysis of the USHA under the Supreme Court's Cort v. Ash ${ }^{11}$ approach to implied right of action questions. ${ }^{12}$ The note concludes that, despite the Supreme Court's recent reluctance to imply a private right of action where Congress has not directly provided for one, the federal courts should permit the prosecution of private claims under the USHA.

Finally, the note examines the implications that a related issuewhether private plaintiffs may sue local housing authorities for alleged violations of the USHA under 42 U.S.C. section 1983-may have on USHA implied right of action analysis. ${ }^{13}$ In light of the Supreme Court's recent recognition, in Wright v. City of Roanoke Redevelopment \& Housing Authority, ${ }^{14}$ of a section 1983 private remedy for alleged violations of

8. See generally Comment, No Implied Cause of Action Under the National Housing Act: $A$ Barrier to a Statutory Right, 22 URB. L. ANN. 249 (1981) [hereinafter Comment, No Implied Cause of Action]. The comment was publislied prior to the reevaluation among the lower federal courts concerning the existence of an implied right of action under the USHA. See also Comment, The Brooke Amendment: Does "Shall Pay as Rent" Give Tenants a Right to Sue?, 37 MERCER L. Rev. 1087 (1986) [hereinafter Comment, The Brooke Amendment]. This comment only discusses the tenant's right to sue in federal court under the percentage-of-income rent ceiling provision, known as the Brooke Amendment. See 42 U.S.C. § 1437a (1982 \& Supp. III 1985). This note focuses on the broader question of whether tenants may, as a general matter, bring private actions under various provisions of the USHA. Inasmuch as the suits brought to date involve many issues unrelated to rent grievances, the relevant issue is whether prospective tenant-plaint:ffs may maintain a private right of action under the USHA regardless of the applicable provision of the Act or HUD regulations.

For additional discussion of implied rights of action under the Brooke Amendment as an isolated USHA provision, see Note, Howard v. Pierce: Implied Causes of Action and the Ongoing Vitality of Cort v. Ash, 80 Nw. U.L. Rev. 722 (1985) [hereinafter Note, Howard v. Pierce].

9. See infra notes $17-36$ and accompanying text.

10. See infra notes $37-44$ and accompanying text.

11. 422 U.S. 66 (1975).

12. See infra notes $45-95$ and accompanying text.

13. See infra notes $96-128$ and accompanying text.

14. 107 S. Ct. 766 (1987). 
the USHA, ${ }^{15}$ the note concludes that the USHA implied right of action issue has become further confused. Nonetheless, the Court's analysis in Wright, by indirectly addressing implied right of action issues, compels the conclusion that private plaintiffs may seek redress of USHA violations not only via section 1983 actions but through more comprehensive implied private actions under the USHA itself. ${ }^{16}$ On this premise, the note concludes that the federal courts should implement Congress's clear intent by immediately recognizing an implied private right of action under the USHA, thereby giving private plaintiffs remedies against the full range of state and federal agency defendants.

\section{The LaW of Implied Private Rights of Action}

The Supreme Court set forth the standards for implication of a private right of action in the seminal case of Cort v. Ash. ${ }^{17}$ In Cort, the plaintiff-shareholders brought a derivative suit based on the alleged violation by corporate directors of federal criminal statutes prohibiting certain expenditures of corporate funds on behalf of political candidates. ${ }^{18}$ The Court held that a private right of action could not be implied under the statutes, which were enacted not for the benefit of shareholders but for the protection of the public at large. ${ }^{19}$ The Court used the opportunity to announce its now-fainiliar four-part test for the implication of private rights of action under federal statutes:

First, is the plaintiff "one of the class for whose especial benefit the statute was enacted,"-that is, does the statute create a federal right in favor of the plaintiff? Second, is there any indication of legislative intent, explicit or implicit, either to create such a remedy or to deny one? Third, is it consistent with the underlying purposes of the legislative scheme to imply such a remedy for the plaintiff? And finally, is the cause of action one traditionally relegated to state law, in an area basically the concern of the States, so that it would be inappropriate to infer a cause of action based solely on federal law? ${ }^{20}$

This test represented less a radical new articulation of doctrine than a concrete synthesis of standards announced in prior case law. ${ }^{21}$ Never-

\footnotetext{
15. Id. at 774 .

16. See infra notes $129-63$ and accompanying text.

17. 422 U.S. 66 (1975).

18. Id. at 68 .

19. Id. at 81-82.

20. Id. at 78 (citations omitted).
}

21. J.I. Case Co. v. Borak, 377 U.S. 426, $432-34$ (1964) (Private enforcement provides a necessary and practical means to enforce the proxy solicitation regulations promulgated under section 14(a) of the Securities Exchange Act of 1934.); Texas \& Pac. Ry. v. Rigsby, 241 U.S. 33, 39 (1916) (" "[W] here a statute enacts, or prohibits a thing for the benefit of a person, he shall have a remedy upon the same statute for the thing enacted for his advantage ...'" "(paraphrasing Anonymous, 6 Mod. 26, 26-27, 87 Eng. Rep. 791, 791 (Q.B. 1703)). 
theless, Cort failed to settle the law and instead triggered a ten-year struggle within the Court over the appropriate reach of Cort's implied private right of action doctrine. ${ }^{22}$

In several post-Cort cases, the Court refined its four-part test and appeared to narrow its scope. Disagreement over the propriety and scope of the Cort test first appeared in Cannon v. University of Chicago, ${ }^{23}$ in which the Court, by a six to three vote, upheld the implication of a private right of action under Title IX of the Education Amendments of 1972. In a concurring opinion, Justices Rehnquist and Stewart expressed their view that direct inquiry into legislative intent was the dispositive feature of the Cort test. ${ }^{24}$ Justice Powell, in dissent, went even further and directly argued for the abandonment of Cort in favor of a test depending exclusively on directly discernible congressional intent. ${ }^{25}$

Within months, this special emphasis on legislative intent won a place in the Court's implied right of action doctrine. In Touche Ross \&

22. See infra notes 23-36 and accompanying text. After Cort, there was considerable disagreement about the practical effect of the decision on the continuing ability of plaintiffs to bring lawsuits in federal court based on implied causes of action. Compare Note, Implied Private Rights of Action-The Cort v. Ash Test-Interaction of "Especial Beneficiary" and Legislative Intent, 24 WAYNE L. REv. 1173, 1184-85 (1978) (Cort, despite its result as to the plaintiff-shareholders, signaled a liberal attitude toward implication of plivate rights of action when plaintiffs are members of a beneficiary class, unless the language of the statute or the legislative history expressly indicates a different legislative intent.) with Note, Implied Private Actions Under Federal Statutes-The Emergence of a Conservative Doctrine, 18 WM. \& MAFY L. REv. 429, 450-57 (1976) (criticizing Cort as imposing unwarranted and highly restrictive test for the implication of private rights of action). See also Mezey, Judicial Interpretation of Legislative Intent: The Role of the Supreme Court in the Implication of Private Rights of Action, 36 RuTGERs L. REV. 53, 76 (1983) (The Court has "clearly demonstrated [its] determination to stand fast against the onslaught of cases asserting a private right of action."); Note, Howard v. Pierce, supra note 8, at 766 (After Cort, courts will "continue to play a role in delineating proper enforcement measures," including implied private rights of action under federal statutes.); Note, Third Party Beneficiary and Implied Right of Action Analysis: The Fiction of One Governmental Intent, 94 YALE L.J. 875, 876-77 (1985) (The Court's implied right of action doctrine has become "increasingly stringent.") [hereinafter Note, Third Party Beneficiary]. It should be noted that these last three publications all discuss the Court's implied private right of action doctrine in light of post-Cort developnients, which appear to restrict the reach of the Cort test.

23. 441 U.S. 677,717 (1979). The Court partially based its holding on a finding that "Title IX was patterned after Title VI of the Civil Rights Act of 1964," id. at 694, under which the United States Court of Appeals for the Fifth Circuit had found an implied right of action 12 years before. Bossier Parish School Bd. v. Lemon, 370 F.2d 847 (5th Cir.), cert. denied, 388 U.S. 911 (1967). Mezey notes that, one year before Cannon, eight of the justices had "assumed that Title VI [of the Civil Rights Act of 1964] allowed a private right of action. Mezey, supra note 22, at $62 \mathrm{n} .61$ (citing Regents of the University of Cal. v. Bakke, 438 U.S. 265 (1978)).

24. Cannon, 441 U.S. at 717-18 (Rehnquist, J., concurring) ("[T]his Court . . should be extremely reluctant to imply a cause of action absent such specificity on the part of the Legislative Branch.").

25. Id. at 749 (Powell, J., dissenting) ("[W]e should not condone the implication of any private action ... absent the most compelling evidence that Congress in fact intended such an action to exist."). 
Co. v. Redington, ${ }^{26}$ the Court held that an implied private right of action was not available under section 17(a) of the Securities Exchange Act of 1934. Justice Rehnquist, now writing for the majority, almost exclusively emphasized statutory construction and legislative history. Finding that both were silent as to a section 17(a) private remedy, the Court proceeded to hold that, because other sections of the Securities Exchange Act expressly provided for private enforcement, implication of a private cause of action was unwarranted. ${ }^{27}$

For some commentators, Touche Ross represented a substantial alteration of the Cort approach; it appears to hold that mquiry into the statute's express language and the legislative history constitutes a "threshold" test-namely, that failure to satisfy the second prong of the Cort test required immediate rejection of an implied cause of action, without further inquiries into the other Cort factors. ${ }^{28}$ This conclusion was apparently reinforced when the Court reemphasized the importance of "legislative intent" to the Cort analysis in Transamerica Mortgage Advisors, Inc. v. Lewis. ${ }^{29}$ In a five-to-four decision, the Court rejected the

26. 442 U.S. $560,569-70$ (1979).

27. Id. at 571-72.

28. Justice White's dissent in Transamerica Mortgage Advisors, Inc. v. Lewis explicitly treats the Touche Ross Court's emphasis on express legislative intent as a threshold test, rather than a complete abdication of Cort in favor of Justice Powell's suggested exclusive reliance on discernible legislative intent. 444 U.S. 11, 34 n.10 (1979) (White, J., dissenting). See supra note 25 and accompanying text. Indeed, nowhere in Touche Ross or subsequent decisions did the Court explicitly reject the Cort analysis in favor of an exclusive "express legislative intent" test. For a discussion of Transamerica, see infra notes 29-31 and accompanying text.

The Court's analysis in Touche Ross too easily brings one to the misleading conclusion that silence on the private enforcement issue in the statute itself or the legislative history necessarily "weights against implication," as some commentators have stated. See, e.g., Comment, No Implied Cause of Action, supra note 8, at 260. Such a reading suggests a marked departure from the Cannon Court's holding that "in situations ... in which it is clear that federal law has granted a class of persons certain rights, it is not necessary to show an intention to create a private cause of action, although an explicit purpose to deny such cause of action would be controlling. " 441 U.S. at 694 (quoting Cort v. Ash, 422 U.S. 66, 82 (1975)). "[T]he Court has long recognized that under certain limited circumstances the failure of Congress [to provide for a private right of action] is not inconsistent with an intent on its part to have such a remedy available to the persons benefited by its legislation." Cannon, 441 U.S. at 717. Touche Ross should not be read to hold that complete congressional silence on the issue of private enforcement automatically triggers rejection of a private remedy; the decision does not so state, thus preserving the quite different inference suggested by the quoted language from Cannon. Instead, Touche Ross merely stands for the proposition that Congress has not been silent when it has affirmatively provided for private enforcement in other sections of the relevant statute, while remaining silent on the question in the particular section under which plaintiffs are suing. As a matter of statutory construction, reference to the entire legislative scheme, by negative implication, constitutes positive evidence of legislative intent. See supra note 27 and accompanying text.

This subtle distinction is particularly important on the issue of whether to imply a private right of action under the USHA. See infra notes 63-74 and accompanying text.

29. 444 U.S. 11, 15-16 (1979). 
implication of a private damages action under the Investment Advisers Act of $1940,{ }^{30}$ holding that the statutory enforcement scheme was so comprehensive that it was highly unlikely that Congress intended to permit private actions under the Act. ${ }^{31}$

The Supreme Court's strong emphasis on legislative intent also appeared in subsequent implied right of action cases. ${ }^{32}$ Nevertheless, while the post-Cort cases clearly represent both a restrictive approach to the implication of private rights of action and "the Court's determination to stand fast against the onslaught of cases asserting a private right of action," 33 the Court has declined to adopt Justice Powell's suggested rejection of Cort in favor of exclusive reliance on express congressional intent. ${ }^{34}$ Instead, in a typical recent implied right of action decision, the Court reaffirmed the Cort test, characterizing it (in light of post-Cort cases) as the appropriate means for determining congressional intent. ${ }^{35}$ It is in this context, of an implied right of action doctrine still in flux and hotly debated by members of the Court, ${ }^{36}$ that the lower courts have addressed the USHA implied right of action question.

30. 15 U.S.C. $\S \S 80 \mathrm{~b}-1$ to $80 \mathrm{~b}-21$ (1982).

31. 444 U.S. at 20. Like Touche Ross, the Transamerica decision is easily read too broadly. The Transamerica Court did not hold that congressional provision of some enforcement mechanisms automatically precludes private enforcement, but instead held that the existence of a comprehensive statutory enforcement scheme precludes implication of a private right of action. In this vein, Touche Ross and Transamerica collapse the second and third Cort factors into a single exercise in statutory construction. The cases merely stand for the proposition that, taken as a whole, statutes may be so comprehensive (Transamerica) or so cleir in their provisions for and (implicit) exclusions of private enforcement (Touche Ross) that legislative intent to exclude private enforcement is easily inferred. When such an inference is possible, an essential element of the Cort test is missing, and implication of a private remedy is rejected. See supra note 28 . This does not mean that the availability of other enforcement mechanisms defeats private enforcement, but instead that it is an important factor to be considered in determining the existence of an implied cause of action. Cort, 422 U.S. at 78.

32. See, e.g., Merrell Dow Pharmaceuticals, Inc. v. Thompson, 106 S. Ct. 3229, 3234-35 n.9, (1986) (reviewing post-Cort cases that stressed strict fidelity to congressional intent in implied right of action cases); Daily Income Fund, Inc. v. Fox, 464 U.S. 523, 536 (1984) ("[O]ur focus must be on the intent of Congress when it enacted the statute in question."); Merrill Lynch, Pierce, Fenner \& Smith, Inc. v. Curran, 456 U.S. 353, 377 (1982) ("Our cases subsequent to [Cort] have plainly stated that our focus must be on 'the intent of Congress.' "); Texas Indus., Inc. v. Radcliff Materials, Inc., 451 U.S. 630, 639 (1981) ("Our focus, as it is in any case involving the implication of a right of action, is on the intent of Congress."); California v. Sierra Club, 451 U.S. 287, 293 (1981) ("[U]ltimate issue is whether Congress intended to create a private right of action ...."); Northwest Airlines, Inc. v. Transport Workers Union, 451 U.S. 77, 91 (1981) (The dispositive question is "whether Congress intended to create the private remedy."); Universities Research Ass'n v. Coutu, 450 U.S. 754, 770 (1981) (Implied right of action analysis requires an inquiry into discernible legislative intent.).

33. Mezey, supra note 22, at 76.

34. See supra note 25 and accompanying text.

35. Daily Income Fund, Inc. v. Fox, 464 U.S. 523, 536 (1984).

36. Every implied right of action case to reach the Supreme Court since Cort, with the exception of Daily Income Fund, has been decided by a five-to-four or six-to-three margin. 
The district and circuit courts have reached widely differing results when called upon to imply private rights of action under the USHA. One court of appeals-the Sixth Circuit ${ }^{37}$-has implied a private right of action while two others-the Fourth Circuit ${ }^{38}$ and the Eleventh Cir-

37. Howard v. Pierce, 738 F.2d 722 (6th Cir. 1984). The primary difficulty for the Howard court was that "nowhere in the legislative history [had it] uncovered an expression of intent either to provide or deny a private means of enforcing the Brooke Amendment." Id. at 727 (citation omitted). The court's approach to this problem highlights the fundamental implied right of action issue. The key to the Howard court's application of Cort lay not in its failure to find affirmative evidence of congressional intent per se, but in its treatment of the apparent absence of explicit or implicit legislative consideration of the private enforcement issue. The court argued that "legislative silence... support[s] the conclusion that Congress did not intend to deny the intended beneficiaries of the Brooke Amendment a private cause of action" and that "no further conclusions concerning Congress' intent can be made convincingly from the legislative history of the Act." Id. at 728.

The conclusion was critical inasmuch as without it the court could not have proceeded to consideration of the third and fourth Cort factors. Had the court decided that the post-Cort cases required rejection of an implied right of action upon a prima facie finding of "congressional silence," or that there was indeed some affirmative legislative intent to deny a right of private enforcement under the USHA, then the case would have been decided on the second Cort factor alone. Instead, under its "no intent to deny" approach, the court was free to conclude, after appropriate consideration of the statutory scheme set up under the USHA, that an implied private right of action would "further the primary goal of ensuring that low income familes are provided with decent, safe housing." Id. at 730. The court permitted the plaintiff to go forward on her implied right of action and remanded the case for further proceedings. Id. at 731.

38. Wright v. City of Roanoke Redev. \& Hous. Auth., 771 F.2d 833 (4th Cir. 1985), rev'd, 107 S. Ct. 766 (1987); Phelps v. Housing Auth., 742 F.2d 816 (4th Cir. 1984); Perry v. Housing Auth., 664 F.2d 1210 (4th Cir. 1981).

Of these decisions, only Perry and Phelps include any direct discussion of the controlling Cort test's application in the context of a lawsuit brought under the USHA or related HUD regulations. The Perry court made an inexplicable inferential leap in concluding that the extent of local authority over federally assisted housing projects represents affirmative evidence that Congress intended to foreclose private enforcement of the USHA. The court argued that the structure of the program and its sparse legislative history made it "plain that the federal enactments sought to create neither rights in the tenants nor duties in the landlords." 664 F.2d at 1215. It is far from clear that this constitutes evidence that Congress intended that private redress of local or federal failures to comply with the terms of the USHA or HUD regulations be foreclosed to injured tenants. The court reached a wholly untenable conclusion: local control over public housing contracts itself establishes the absence of enforceable federal rights in low income tenants. The argument is unpersuasive because it ties together two totally unrelated concepts: the mechanical structure of the USHA program and legislative intent as to private enforcement of the Act.

Because the court's analysis of the second Cort factor is exclusively limited to this fatally flawed argument, Perry ultimately lends little or no guidance on the question of congressional intent. As a practical matter, the court failed to discuss the issue at all.

1n addition, the Perry court's formulation inexplicably imputes to the Supreme Court utter redundancy in separating out the third and fourth Cort factors as distinct avenues of necessary inquiry. The Perry analysis is therefore flawed, insofar as it flies in the face of any reasonable reading of Cort and the post-Cort decisions, which themselves undertake direct analysis of statutory schemes of enforcement and their compatability with the implication of implied private rights of action.

For a discussion of related flaws in the district court's opinion in Perry, 486 F. Supp. 498 (D.S.C. 1980), see Comment, No Implied Cause of Action, supra note 8, at 265-68. 
cuit $^{39}$ - have refused to imply a private right of action. In addition, one district court has implied a private right of action, ${ }^{40}$ and two have refused to imply a private right of action under the USHA. ${ }^{41}$ The remaining federal courts that have ruled on the question have undertaken no independent analysis, relying instead on available precedents or an indirect denial of an implied right of action. ${ }^{42}$

Analysis of the question is clearly complicated by confusion in the lower courts over the appropriate application of Cort v. Ash and subsequent cases ${ }^{43}$ and by the close relationship to the implied right of action issue of another difficult question-whether plaintiffs can bring an action under 42 U.S.C. section 1983 for alleged violations of the USHA. ${ }^{44}$

39. Nelson v. Greater Gadsden Hous. Auth., 802 F.2d 405, 407 (11th Cir. 1986) ("It is now clear in this Circuit that tenants in Federal Public Housing have ... [no] implied private right of action to enforce the rent provisions of the Brooke Amendment."); Brown v. Housing Auth., 784 F.2d 1533, 1538-39 (11th Cir. 1986) (following the Fourth Circuit's application of the Cort factors in Perry).

40. Silva v. East Providence Hous. Auth., 423 F. Supp. 453, 46465 (D.R.I. 1976) (allowing prospective tenants of lower-rent housing to bring an action against HUD for terminating a building contract), rev'd on other grounds, 565 F.2d 1217 (1st Cir. 1977).

41. Stone v. District of Columbia, 572 F. Supp. 976, 978-80 (D.D.C. 1983) (finding no strong evidence of congressional intent to create private right of action under 42 U.S.C. section 1437a); McGhee v. Housing Auth., 543 F. Supp. 607, 608-10 (M.D. Ala. 1982) (same).

42. See, e.g., Samuels v. District of Columbia, 770 F.2d 184, 201 (D.C. Cir. 1985) ("Because the plaintiffs can redress [the USHA] violation in a section 1983 action, we need not ... consider whether the plaintiffs could also succeed under their constitutional, implied private right of action ... theor[y]."); Beckham v. New York City Hous. Auth., 755 F.2d 1074, 1076-77 (2d Cir. 1985) (implied right of action rejected without discussion of Cort factors); Davis v. City of Toledo, 54 F.R.D. 386, 388 (N.D. Ohio 1970) (discussing section 1983 remedies alone).

43. See supra notes $17-36$ and accompanying text.

44. For a full discussion of the problems posed by the similarity of the section 1983 and implied right of action issues, see infra notes $96-161$ and accompanying text. The section 1983 claims have apparently arisen as a result of fears on the part of many plaintiffs that the federal courts will refuse to imply private rights of action, in light of facially restrictive post-Cort decisions. See Mezey, supra note 22 , at $76-88$.

Section 1983 provides, in relevant part:

Every person who, under color of any statute ... of any State or Territory ... subjects, or causes to be subjected, any citizen of the United States or other person within the jurisdiction thereof to the deprivation of any rights, privileges, or immunities secured by the Constitution and laws, shall be liable to the party injured in an action at law, suit in equity, or other proper proceeding for redress.

42 U.S.C. $\S 1983$ (1982) (emphasis addled). In general, plaintiffs have argued that local housing authorities are subject to section 1983 claims because they act under the authority of state law and therefore become amenable to suit for any action inconsistent with the USHA or related HUD regulations. See, e.g., Wright v. City of Roanoke Redev. \& Hous. Auth., 107 S. Ct. 766, 769-70 (1987). For a full discussion of Wright and its implications for USHA implied right of action analysis, see infra notes 109-63 and accompanying text. For present purposes, it suffices to note that Wright did not present the USHA implied right of action question. The Wright Court only recognized the validity of a section 1983 action against local housing authorities and did not explicitly address the implication problem. Id. at 774. The USHA implied private right of action question thus remains a live issue. Prospective plaintiffs with claims against HUD, for example, will not be able to take advantage of the permissibility of a section 1983 claim, because section 1983 only applies 
Judges have differed over whether the four-part test of Cort v. Ash continues to apply, and whether it is still necessary in any case to apply all four Cort factors. The issue, therefore, presents unsettled questions requiring further analysis under prevailing law.

\section{The EXISTENCE of AN IMPLIEd Right OF ACtion UNDER THE USHA}

\section{A. The Continuing Applicability of Cort v. Ash.}

The threshold question is whether the Cort $v$. Ash test still provides the proper framework for analysis of implied right of action questions. The Supreme Court has not overruled Cort, either expressly or impliedly. ${ }^{45}$ The relevant issue, therefore, is the extent to which post-Cort decisions have altered the implied right of action doctrine. A review of the decisions reveals that while the Court has placed special emphasis on discerning legislative intent, the Cort test remains fundamentally intact.

Touche Ross, Transamerica, and subsequent decisions reemphasized the Cort fornulation's focus on discerning legislative intent. Yet neither decision repudiates the basic Cort framework. Instead, the Court gradually has redirected the focus of its implied right of action doctrine toward issues that were always at the heart of Cort.

It is true that in Cort v. Ash, the Court set forth four factors that it considered "relevant" in determining whether a private remedy is implicit in a statute not expressly providing one. But the Court did not decide that each of these factors is entitled to equal weight. The central inquiry remains whether Congress intended to create, either expressly or by implication, a private cause of action. ${ }^{46}$

This suggests that the Cort test should now itself be considered a means of discerning probable legislative intent; in other words, the question of congressional intent is no longer merely one element of the test, but the object of analysis under all four Cort factors. Cort controls the implication of private rights under the USHA, and the proper approach is to apply its test, taking care to "focus carefully on 'the intent of

to state actors, not federal actors. These plaintiffs will therefore continue to argue that an implied private right of action exists under the USHA.

The Supreme Court decided Wright against the background of its own repeated recognition of the validity of section 1983 actions premised on alleged violations of various federal statutes. The standards for permitting such actions were announced in Middlesex County Sewerage Auth. v. National Sea Clammers Ass'n, 453 U.S. 1 (1981); Pennhurst State School \& Hosp. v. Halderman, 451 U.S. 1 (1981); and Maine v. Thiboutot, 448 U.S. 1 (1980).

For further discussion of the section 1983 issue, see Mezey, supra note 22, at 76-88; Comment, The Brooke Amendment, supra note 8, at 1104-09.

45. Indeed, in a recent implied right of action case, the Court reaffirmed the Cort test. See Daily Income Fund, Inc. v. Fox, 464 U.S. 523, 535-36 (1984).

46. Touche Ross \& Co. v. Redington, 442 U.S. 560, 575 (1979). 


\section{Congress." "47}

This characterization of the proper application of Cort is crucial to an understanding of the flaws in some courts' discussion of the implied right of action question; and in fact, it shows that none of the lower federal courts, including those that have reached a result compatible with that suggested later in this note, have appropriately analyzed the USHA implied right of action question. If the Cort factors, as suggested above and confirmed by the Court itself, collectively represent "criteria ... primarily focused on the intent of Congress in enacting the statute under review," 48 courts should undertake an exhaustive analysis of all four elements of the Cort test whenever they are confronted with an implied private right of action problem. In other words, it is not the case that the second factor of the original Cort test, which requires examination of any evidence of congressional intent in the statute itself or the legislative history, is now the sole meaningful or dispositive reference point. Instead, it should be understood that courts are still compelled to "carefully analyze the four factors that Cort identifies as indicative of [legislative] intent." 49 It is in this context that this note undertakes an analysis of the USHA implied private right of action question.

\section{B. Application of the Cort Test.}

1. Are Tenants Members of the Special Class of Citizens Congress Intended to Benefit? There is little question that lower-income families-the tenants or prospective tenants of USHA-assisted housing projects-are the intended beneficiaries of the Act. The initial reference point is the USHA policy declaration, which is phrased in language "expressly identif[ying] the class Congress intended to benefit." 50 The legislature explicitly intended "to remedy the unsafe and unsanitary housing conditions and the acute shortage of decent, safe, and sanitary dwellings

47. Stone v. District of Columbia, 572 F. Supp. 976, 979 (D.D.C. 1983) (quoting Merrill Lynch, Pierce, Fenner \& Smith, Inc. v. Curran, 456 U.S. 353, 377 (1982)). As this note later explains, infra notes 70-74 and accompanying text, the elevation of legislative intent to special importance in the Cort analysis does not itself suggest what conclusion should be drawn when no legislative intent-either to create or deny an implied private right of action-is readily discernible from statutory language or legislative history. The following discussion suggests that, although the lower federal courts are correct that the question of legislative intent has taken on especial significance in implication analysis, they have erred in concluding that the absence of direct congressional expressions of intent should automatically result in rejection of an implied private right of action.

48. Merrill Lynch, Pierce, Fenner \& Smith, Inc. v. Curran, 456 U.S. 353, 377 (1982).

49. Cannon v. University of Chicaģo, 441 U.S. 677, 688 (1979) (emphasis added); see also Daily Income Fund, Inc. v. Fox, 464 U.S. 523, 535-36 (1984) (characterizing Cort factors collectively as indicia of legislative intent).

50. Cannoll, 441 U.S. at 690. 
for families of lower income." 51 This policy statement alone, of course, does not create "enforceable rights" in lower-income families eligible or prospectively eligible for tenancy in federally-assisted housing. Nevertheless, the substantive provisions of the USHA that follow the policy statement confer particular benefits on the assisted class also. The USHA's percentage-of-income rent ceilings, ${ }^{52}$ for example, clearly constitute "a direct mandate, creating both a right of tenants to limitations on rent and a duty of landlords and housing authorities to ensure reduced rent."53 By providing that tenants "shall pay as rent" the prescribed maxiinum percentages of their mcome, ${ }^{54}$ the statute affirmatively commands that tenants shall be free from the assessment of monthly rent deemed excessive as a matter of federal policy. It is precisely this kind of right- or duty-creating language that is dispositive under the first Cort factor. It is, therefore, impossible to argue that the intended beneficiaries of the provision were persons other than existing or prospective tenants of public housing assisted under the USHA.

Other provisions of the USHA establish that the primary beneficiaries of the statute-those persons in whoin the Act vests affirmative rights-are lower-income families in need of decent, affordable housing. For exainple, the USHA variously provides for local housing authorities' establishment, as a precondition of federal assistance, of "tenant selection criteria which give[] preference to fannilies which [currently] occupy substandard housing"; 55 for the pronulgation by HUD of regulations requiring local housing authorities to establish and "fully and effectively [enforce]" acceptable "standards of tenant security"; 56 and for "the developinent by local housing authority managements of viable homeownership opportunity programs for lower income families." 57 Each of these provisions redounds with particularity to "the benefit of a special class." 58 This conclusion is reinforced by additional language in the USHA, broadly defining the types of housing eligible for federal assistance ${ }^{59}$ - a definition expressly adopted "[f]or the purpose of aiding lower-

51. 42 U.S.C. $\S 1437$ (1982) (emphasis added).

52. 42 U.S.C. § 1437a (1982 \& Supp. III 1985) (the "Brooke Amendment").

53. Note, Howard v. Pierce, supra note 8, at 751 .

54. 42 U.S.C. $\S 1437$ a(a) (1982 \& Supp. III 1985).

55. 42 U.S.C. $\$ 1437 d(c)(4)(A)$ (Supp. III 1985).

56. 42 U.S.C. $\S 1437 \mathrm{~d}(\mathrm{c})(4)(C)$ (1982); see also 24 C.F.R. $\S 966.4$ (e) (1987) (HUD regulations mandating inclusion of minimum safety and upkeep provisions in leases between tenants and local housing authorities).

57. 42 U.S.C. $\$ 1437 \mathrm{~d}(\mathrm{c})(4)(\mathrm{D})(1982)$.

58. Cannon v. University of Chicago, 441 U.S. 677,689 (1979).

59. See 42 U.S.C. $\$ 1437 f(a)$ (Supp. III 1985) ("[A]ssistance payments may be made with respect to existing housing ...."); cf. 42 U.S.C. $\S 1437 \mathrm{f}(\mathrm{a})$ (1982) ("[A]ssistance payments may be made with respect to existing, newly constructed, and substantially rehabilitated housing ...."). 
income families in obtaining a decent place to live."60

Indeed, the entire statute is explicitly written with an eye toward benefiting lower-income families in general and public housing tenants in particular. Therefore, it is hardly surprising that the lower federal courts have almost universally agreed that lower-income tenants are the "especial class" benefited under the Act. ${ }^{61}$ And as Justice Stevens carefully noted in Cannon, statutory language that is drawn with the particular purpose of benefiting a discrete class of persons-thereby creating rights in that class and imposing duties on its behalf-is "generally ... the most accurate indicator of the propriety of imphication of a cause of action."62 Thus, the USHA by its terms satisfies the first element of the Cort test.

2. The Language of the Statute and Its Legislative History as Indicia of Congressional Intent. As the courts that have considered the USHA implied right of action problem have repeatedly noted, ${ }^{63}$ the statutory language and the available legislative history contain little or no evidence of congressional intent either to grant or to deny tenants an implied private right of action. Only two decisions-Howard v. Pierce 64 and McGhee v. Housing Authority of Lanett ${ }^{65}$-find any indication on the face of the statute of whether Congress intended to permit private enforcement of the USHA. The Howard and McGhee courts each noted that Congress had provided that HUD "inay sue and be sued ... with respect to its functions under the United States Housing Act of 1937."66 In Howard, Judge Celebrezze was only able to read this sovereign immunity waiver as "some evidence of a general intent to permit an action against HUD," but not as an indication of "[w] hether Congress intended private enforcement of [the USHA]."67 Similarly, in McGhee, Judge

60. 42 U.S.C. § $1437 f(a)$ (Supp. III 1985).

61. See, e.g., Howard v. Pierce, 738 F.2d 722, 725 (6th Cir. 1984) (Lower-income tenants are "the intended beneficiaries of the Brovke Amendment in particular and [the USHA] in general."); Falzarano v. United States, 607 F.2d 506, 509 (1st Cir. 1979) ("Low and moderate income tenants are indisputably the prime beneficiaries of the National Housing Act."); M.B. Guran Co. v. City of Akron, 546 F.2d 201, 204 (6th Cir. 1976) (The USHA was enacted for the benefit of "persons who inhabit inadequate housing."); Stone v. District of Columbia, 572 F. Supp. 976, 980 (D.D.C. 1983) ("To be sure, [lower-income tenants] are among the intended beneficiaries of Section 1437a . ..."); McGhee v. Housing Auth., 543 F. Supp. 607, 608 (M.D. Ala. 1982) (Public housing tenants appear to have a "vested ... property right to public housing at the rental rate" specified by law.); $c f$. Perry v. Housing Auth., 664 F.2d 1210, 1213 (4th Cir. 1981) (Tenants are only indirect beneficiaries of the USHA; a direct benefit is conferred only on states and local housing authorities.).

62. Cannon, 441 U.S, at 690 n.13.

63. See supra notes $37-44$ and accompanying text.

64. 738 F.2d 722 (6th Cir. 1984); see supra note 37.

65. 543 F. Supp. 607 (M.D. Ala. 1982); see supra note 41.

66. 42 U.S.C. § 1404a (1982); see Howard, 738 F.2d at 727; McGhee, 543 F. Supp. at 609 n.l.

67. 738 F.2d at 727-28. The Howard court also failed to find any indication of congressional intent on the private enforcement issue in the legislative history of the USHA. See supra note 37. 
Varner conceded that while the "provision may indicate a congressional intent to allow suit against [HUD], it cannot be read to be an indication of congressional intent to allow private actions against local public housing authorities." 68 In the latter case, however, the court's language is clearly dicta, since plaintiffs had not attempted to join HUD as a defendant.

Even. if the courts are correct in their interpretation of the provision, the point is helpful only in a limited way. No matter how it is applied, this sovereign immunity waiver leaves two fundamental questions unanswered: whether a local housing authority can be sued, ${ }^{69}$ and, in any event, who may sue an agency (imcluding HUD) under the implied private right of action. The legislative history is devoid of guidance even as to the scope of the waiver provision. In examining the USHA and its legislative history, the courts have been confronted with a graphic illustration of the Supreme Court's observation that "the legislative history of a statute that does not expressly create or deny a private remedy will typically be equally silent or ambignous on the question."70

The dispositive question therefore is what consequences should follow from "congressional silence." In addressing this question obvious analytical difficulties appear among the lower court opinions. Some courts have held that congressional silence automatically requires rejection of the asserted implied right of action, while others have held that silence merely requires further analysis under the Cort test. ${ }^{71}$

The flaw in the former conclusion is readily apparent. Had Congress "spoken," the issue of "iniplication" would be moot or could hardly be said to have arisen in the first place. Undertaking implication analysis necessarily presupposes the absence of express congressional treatment of the private enforcement question. The significance of the second Cort factor, therefore, is that it draws courts' attention to any indirect evidence of congressional intent in the statute itself or its legislative history. To attempt to draw conclusions from the same facial congressional silence that gives rise to the need for implication analysis in the first instance begs the question.

In this sense, absolute reliance on the presence or absence of direct expressions of congressional intent undermines the entire foundation of Cort v. Ash. But the Court has not overruled Cort, and has instead chosen to repeat that, in order to imply a private right of action under a

68. 543 F. Supp. at 609 n.1.

69. Both courts held that local housing authorities could not be sued on an implied right of action theory under the USHA. See Howard, 738 F.2d at 730; McGhee, 543 F. Supp. at 610.

70. Cannon v. University of Chicago, 441 U.S. 677, 694 (1979).

71. See supra notes $17-42$ and accompanying text. 
given federal statute, " it is not necessary to show an intention to create a private cause of action, although an explicit purpose to deny such cause of action would be controlling." "72 The post-Cort cases cannot and should not be read to alter this rule. ${ }^{73}$ Even in its most restrictive implied right of action decisions the Court has expressly recognized:

[W] hile the absence of anything in the legislative history that indicates an intention to confer ally private right of action is hardly helpful to the [plaintiff], it does not automatically undermine his position. . . . [T] he failure of Congress expressly to consider a private remedy is not inevitably inconsistent with an intent on its part to make such a remedy available. Such an intent may appear implicitly in the language or structure of the statute, or in the circumstances of its enactment. ${ }^{74}$

On the particular question of whether an implied right of action exists under the USHA, therefore, a completion of the Cort analysis is required, even under the Court's more restrictive decisions. Essentially, congressional silence leads to the wholly unremarkable conclusion that courts must look elsewhere-to indicia of congressional intent other than the language of the statute itself or the legislative history-to complete the analysis and reach a supportable conclusion on any given implied right of action question. This was and still is the essence of Cort-an analytical distinction that has been ignored by those courts which reached their decisions after consideration of the statutory language and the legislative history materials alone.

3. The "Statutory Scheme" The third Cort factor requires examination of whether it is "consistent with the underlying purposes of the legislative scheme to imply . . a [private] remedy for the plaintiff."7s This prong of the Cort test has been characterized as involving "the answers to two questions: (1) will private remedies interfere with the discretionary actions of the administrative agency [here, HUD], and (2) are the agency's own enforcement mechanisms adequate to protect the inter-

72. Cannon, 441 U.S. at 694 (quoting Cort v. Ash, 422 U.S. 66, 82 (1975)).

73. See supra notes $28 \& 31$.

74. Transamerica Mortgage Advisors, Inc. v. Lewis, 444 U.S. 11, 18 (1979) (emphasis added) (citation omitted); see also Touche Ross \& Co. v. Redington, 442 U.S. 560 (1979). The Touche Ross Court also recognized that the Cort factors collectively address the central question of legislative intent, id. at 575-76, and decided the case merely on the grounds that "the plain language of the statutory provision weighs against implication of a private remedy." Id. at 571 (emphasis added). Given this latter finding, Touche Ross indeed cannot be read as considering the question of appropriate analysis in the face of "congressional silence" at all; the holding clearly follows from an entirely different situation, in which Congress was not "silent." See supra note 28.

Touche Ross and Transamerica nevertheless do stand for the proposition that congressional silence does not permit courts freely to "consider the utility of a private remedy." Transamerica, 444 U.S. at 23. This note does not take issue with that conclusion.

75. Cort, 422 U.S. at 78. 
ests of the plaintiffs?"76 From this point of reference, examination of the USHA "statutory scheme" shows that an implied private right of action is consistent with Congress's purpose in enacting the statute.

The issue is whether the USHA statutory scheme is constructed such that private enforcement in a federal forum furthers the role Congress expected HUD and local housing authorities to play in carrying out the goals of a low-income public housing assistance program. As in Transamerica, the statutory enforcement scheme may be so extensive that Congress cannot reasonably be said to have expected that private enforcement was either necessary or prudent. ${ }^{77}$ But when a statute provides few or no mechanisms through which the primary right holders can vindicate their claims, private enforcement may be "necessary or at least helpful to the accomplishment of the statutory purpose."78

At least one court has correctly noted that "[c]onspicuously absent from the [USHA] are private enforcement mechanisms."79 While HUD is itself given the right to "sue and be sued" under provisions of the USHA, ${ }^{80}$ it is far from clear that this gives tenants the right to privately enforce the USHA in federal courts, especially when their grievances involve the acts (or failures to act) of local housing authorities. ${ }^{81}$ Under HUD regulations, however, tenants are putatively granted a right to challenge local housing authority action..$^{82}$

Even a cursory glance at the regulations, however, reveals that this grievance hearing remedy is extremely limited and of little practical value. The grievance procedure is available only to current tenants of federally assisted housing projects; $; 3$ prospective tenants with grievances, such as those in Silva v. East Providence Housing Authority, ${ }^{84}$ are therefore left with no administrative remedy under the regulations. In any event, local housing authorities appear to be free to ignore the results of a hearing under the grievance procedure, ${ }^{85}$ leaving complainants with no

76. Note, Howard v. Pierce, supra note 8, at 753-54.

77. For a discussion of Transamerica in this regard, see supra notes 29-31 and accompanying text.

78. Cannon v. University of Chicago, 441 U.S. 677, 703 (1979). Justice Stevens characterized the Court as "decidedly receptive" to implication of a private cause of action in these circumstances. Id.

79. Howard v. Pierce, 738 F.2d 722, 729 (6th Cir. 1984).

80. 42 U.S.C. $\S 1404 a$ (1982).

81. See supra notes $66-69$ and accompanying text.

82. 24 C.F.R. $\S \S 966.50-966.59$ (1987).

83. 24 C.F.R. $\S \S 966.51(\mathrm{a}), 966.53(\mathrm{f})$ (1987).

84. 423 F. Supp. 453 (D.R.I. 1976), rev'd on other grounds, 565 F.2d 1217 (1st Cir. 1977).

85. The grievance procedure regulations provide, in relevant part:

(b) The decision of the hearing officer or hearing panel shall be binding on the [local housing authority] which shall take all actions, or refrain from any actions, necessary to 
alternative but to seek judicial relief. Perhaps most important, the grievance procedure does not provide for action against HUD itself, leaving plaintiffs whose complaints directly involve HUD action (or inaction), like those in Howard v. Pierce, ${ }^{86}$ no administrative recourse.

In these kinds of circumstances implication of a private right of action on behalf of the primary statutory beneficiaries is most appropriate. In Cannon v. University of Chicago, ${ }^{87}$ the Supreme Court emphasized that enforcement mechanisms under Title IX of the Education Amendments were especially inadequate, giving rise to the inference that Congress had implicitly contemplated that private enforcement would supplement the statutory scheme. In the case of the USHA, the argument appears to be even stronger. Without the right to seek private enforcement of the Act's provisions, tenants and prospective tenants would be left with no recourse in the face of violations of the USHA or related HUD regulations by HUD itself or a local housing authority. Even in the Court's most restrictive implied right of action cases, it has refused to allow private enforcement only when there is "evidence to support the view" that the statutory enforcement scheme "was intended to provide the exclusive remedy" for violations of statutory beneficiaries' rights. ${ }^{88}$ When, as under the USHA, the statute leaves open the possibility that a number of grievances cannot be remedied, it is far more likely that Congress intended to permit private enforcement.

Without an implied private right of action, lower-income beneficiaries of the USHA would be left without a remedy in many unacceptable circumstances. Tenants and prospective tenants could not, for example, challenge HUD regulations that left loopholes through which local housing authorities could charge rents in excess of the maximums prescribed in the Brooke Amendment. ${ }^{89}$ Nor could they seek injunctive relief when a landlord failed to provide adequate grievance procedures in

carry out the decision unless the [local housing authority] determines within a reasonable time, and promptly notifies the complainant of its determination, that

-..

(2) The decision of the hearing officer or hearing panel is contrary to applicable Federal, State or local law, HUD regulations or requirements of the annual contributions contract between HUD and the [local housing authority].

24 C.F.R. § 966.57(b) (1987) (emphasis added).

86. 738 F.2d 722 (6th Cir. 1984). For discussion of the claim presented in Howard, see supra note 37.

87. 441 U.S. 677, $708 \mathrm{n} .42$ (1979) (noting that HEW candidly admitted lack of resources necessary to enforce Title IX).

88. Touche Ross \& Co. v. Redington, 442 U.S. 560, 573 (1979) (emphasis added) (discussing statutorily created remedies for violations of Securities Exchange Act's proscription of material misstatements in proxy solicitations).

89. See Howard, 738 F.2d at 728-29. 
tenant leases as specified by HUD regulations..$^{90}$ Whatever the scenario, the crucial point is not that private enforcement is desirable, but that the lack of alternatives in the statutory scheme gives rise to a strong inference that Congress intended to permit private causes of action in lieu thereof. Therefore, private enforcement of the USHA is consistent with the established inechanisms through which Congress sought to further the USHA's stated purposes.

4. The Prospective Claims as Matters "Best Left to the States." The final Cort factor requires an examination of whether implication of a private right of action under the USHA would result in interference with matters "traditionally relegated to state law." 91 The USHA policy declaration $^{92}$ makes it clear that, through the Act, "tlie federal government ... assumed responsibility for housing the nation's poor."93 The USHA represents a congressional determination that lower-income housing problems are necessarily a national concern.

The conclusion of some lower federal courts that USHA-related disputes exclusively present questions of state landlord/tenant law ${ }^{94}$ is flawed for two reasons. First, not all possible violations of the USHA or HUD regulations necessarily involve breaclies of a lease between a local housing authority and a plaintiff-tenant. ${ }^{95}$ Second, and more important, even grievances over leases have been conclusively made federal questions by the USHA. Any given dispute may involve not only construction of specific provisions of the USHA or HUD regulations, but also consideration of the USHA's underlying policies and purpose. Those courts holding that USHA claims present landlord/tenant questions alone have simply not gone far enough. The lyppotletical plaintiff, proceeding on an implied right of action under the USHA, is not suing on his lease alone; lie is alleging the breach of federal policy through the violation of specific provisions of the statute representing that policy. In this sense, landlord/tenant law, wlile not irrelevant, is clearly a secondary issue.

The central issue presented by an implied right of action under the USHA is, by the terms of the statute, a matter whicls cannot be said to implicate concerns traditionally relegated to state law. Thus, under the fourth Cort factor, it is appropriate to permit an inplied right of action under tlie USHA to go forward.

\footnotetext{
90. See 24 C.F.R. $\S 966.50$ (1987).

91. Cort, 422 U.S. at 78.

92. 42 U.S.C. $\S 1437$ (1982).

93. Note, Howard v. Pierce, supra note 8 , at 755.

94. See, e.g., Perry v. Housing Auth., 664 F.2d 1210, 1216 (4th Cir. 1981).

95. See, e.g., Howard v. Pierce, 738 F.2d 722 (6th Cir. 1984).
} 


\section{Section 1983 and Implied Private Rights of Action UNDER THE USHA}

The series of lower court cases addressing the related questions of whether an implied private right of action exists under the USHA ${ }^{96}$ and whether private plaintiffs can seek redress of USHA violations via section 1983 civil rights actions ${ }^{97}$ culminated recently with the Supreme Court's decision in Wright v. City of Roanoke Redevelopment \& Housing Authority. 98 In Wright, the Court held that the plaintiffs could maintain an action against local housing authorities, under 42 U.S.C. section 1983, for alleged violations of the USHA. ${ }^{99}$ The Court did not, however, discuss the broader implied private right of action question. While much of the Court's analysis of the section 1983 issue is relevant for resolution of the implied right of action problem, ${ }^{100}$ the Court's failure to address the latter issue squarely leaves troublesome questions unanswered and in fact serves only to confuse the entire USHA private enforcement problem. This note concludes that the Wright Court should have addressed and settled the implied private right of action issue, and, moreover, that the Court's result could not have been reached without tacit recognition of the existence of an implied private right of action under the USHA.

\section{A. Section 1983 Actions to Enforce Federal Statutes.}

In Maine v. Thiboutot, ${ }^{101}$ the Supreme Court held that section 1983 is available to plaintiffs seeking redress of alleged violations of federal statutes by state actors. As with the Court's implied right of action decisions, ${ }^{102}$ the Thiboutot Court opened the federal courthouse doors to hundreds of private plaintiffs for whom relief from violations of federal statutes was previously unavailable. The Thiboutot Court apparently recognized a damage remedy for all violations of a federal statute by state officials, "includ[ing] official failure to comply with federal requirements in the operation of programs of federal-state cooperation." 103 Presumably, therefore, the section 1983 remedy recognized in Thiboutot extended to violations even of purely remedial social welfare statutes like

\footnotetext{
96. See supra notes $37-44$ and accompanying text.

97. See supra note 44 and accompanying text.

98. 107 S. Ct. 766 (1987).

99. Id. at 769 .

100. See infra notes $129-63$ and accompanying text.

101. 448 U.S. 1 (1980).

102. See supra notes 17-36 and accompanying text.

103. H. Fink \& M. Tushnet, Federal Jurisdiction: Policy and Practice 779-80 (2nd
} ed. 1987). 
the USHA. ${ }^{104}$

In subsequent decisions, however, the Court restricted the reach of Thiboutot by exempting at least two broad categories of federal statutes from coverage under the section 1983 remedy. In Pennhurst State School and Hospital v. Halderman, ${ }^{105}$ the Court held that the section 1983 remedy covers violations only of federal statutes that vested "substantive rights" in the putative plaintiffs. ${ }^{106}$ In Middlesex County Sewerage Authority v. National Sea Clammers Association, ${ }^{107}$ the Court further restricted the reach of Thiboutot by holding that rehef is unavailable when Congress has directly or indirectly expressed an intent to foreclose the section 1983 remedy. The Court concluded that congressional intent to preclude section 1983 enforcement of a federal statute may be found in a particularly comprehensive independent scheme of enforcement in the statute itself. ${ }^{108}$ Thus, remedial statutes might not be subject to private enforcement via section 1983 actions, given the Middlesex presumption that Congress intended to foreclose section 1983 enforcement when the statute at issue includes its own broad enforcement provisions.

Thiboutot, Pennhurst and Middlesex appear to represent a relatively straightforward standard: plaintiffs may seek rehef, via a section 1983 action, for violations by state actors of a federal statute that creates substantive rights in the plaintiffs, so long as Congress has not expressly or impliedly foreclosed section 1983 enforcement. Nevertheless, it remains unclear whether section 1983 remedies are available in the specific context of remedial statutes, like the USHA, which are ambiguous in the conferral of substantive rights and virtually silent on the issue of private enforcement. It was in this setting that the Court decided, in Wright $v$. City of Roanoke Redevelopment \& Housing Authority, ${ }^{109}$ whether section 1983 relief is available for violations of the USHA by state officials.

104. Indeed, in his dissent in Thiboutot, Justice Powell listed the USHA as one of the remedial statutes that might be covered by the section 1983 remedy recognized by the majority opinion. Thiboutot, 448 U.S. 11 app. at 36 (Powell, J., dissenting).

105. 451 U.S. 1 (1981).

106. Id. at 21. As to the specific statute involved in Pennhurst-the Developmentally Disabled Assistance and Bill of Rights Act-the Court held that a "Patient Bill of Rights" included in the Act was not intended by Congress to give patients any substantive rights or impose any affirmative duties on the states. Id. at 21-22.

107. 453 U.S. 1 (1981).

108. Id. at 21 .

109. 107 S. Ct. 766 (1987). 
B. Wright v. City of Roanoke Redevelopment and Housing Authority.

The Wright Court considered a section 1983 action brought by the tenants of an USHA-assisted, lower-income housing project in Roanoke, Virginia against the local public housing authority for alleged violations of the rent limitations of the USHA's Brooke Amendment. ${ }^{110}$ The plaintiffs claimed that, under prior case law and various HUD regulations, rent surcharges for tenants' utihty usage fell within the definition of "rent" under the Brooke Amendment, and that excessive utility surcharges imposed by local authorities therefore constituted violations of the Amendment's rent ceilimgs.

The United States District Court for the Western District of Virginia ${ }^{111}$ and the United States Court of Appeals for the Fourth Circuit ${ }^{112}$ rejected the plaintiffs' claims, on the ground that no section 1983 cause of action existed to redress alleged violations of the Brooke Amendment by local public housing authorities. Relying on previous Fourth Circuit cases reaching a similar result, ${ }^{113}$ both courts concluded that private enforcement of the USHA was unavailable through either an implied private right of action or a section 1983 suit against local public housing authorities.

In a five-to-four decision, in which Justice White wrote for the majority, the Supreme Court reversed the lower court holding. ${ }^{114}$ The Court applied the Thiboutot, Pennhurst and Middlesex tests and concluded that "the benefits Congress intended to confer on tenants are sufficiently specific and definite to qualify as enforceable rights under Pennhurst and $\S 1983$, rights that are not . . . beyond the competence of the judiciary to enforce," 115 and that "nothing in the Housing Act or the Brooke Amendment evidences that Congress intended to preclude [the plaintiffs'] $§ 1983$ claim." 116 For the Court, these holdings led to the conclusion that a section 1983 cause of action was available to enforce the Brooke Amendment's rent limitations.

In reaching its decision, the Wright Court undertook a bifurcated analysis: first, under Middlesex, of whether Congress had expressly or

110. Id. at 768-70; see 42 U.S.C. \$ 1437a (1982 \& Supp. III 1985) (the "Brooke Amendment").

111. Wright v. City of Roanoke Redev. \& Hous. Auth., 605 F. Supp. 532, 536 (W.D. Va. 1984).

112. Wright v. City of Roanoke Redev. \& Hous. Auth., 771 F.2d 833, 873 n.9 (4th Cir. 1985).

113. See Phelps v. Housing Auth., 742 F.2d 816 (4th Cir. 1984); Perry v. Housing Auth., 664 F.2d 1210 (4th Cir. 1981). Phelps and Perry are discussed in detail at supra note 38 and accompanying text.

114. $107 \mathrm{~S}$. Ct. at 768-69.

115. Id. at 775 .

116. Id. at 774 . 
impliedly precluded section 1983 enforcement, ${ }^{117}$ and second, under Pennhurst, of whether enforceable rights were created in tenants via the Brooke Amendment. ${ }^{118}$ The Court's preclusion analysis began with the restatement of a strong presumption against preclusion of section 1983 enforcement. ${ }^{119}$ The Court found that the respondent housing authority had failed to defeat this presumption, which by its terms shifts the burden of persuasion on the preclusion issue to state actor defendants. ${ }^{120}$

As an initial matter, the Court found in the USHA no express grant of judicial remedies or comprehensive remedial schemes like those which, in Middlesex and Smith, had triggered a presumption of congressional intent to foreclose independent section 1983 enforcement.121 "Indeed, the only private remedy provided for [in the Brooke Amendment or elsewhere in the USHA] is the local grievance procedures which the Act now requires."122 More important, the Court found affirmative evidence of congressional intent to permit private enforcement. The Court argued that because Congress failed to vest exclusive authority to enforce the USHA in HUD, it affirmatively contemplated the availability of private enforcement mechanisms. The key, therefore, was that the congressional failure to provide a comprehensive remedial scheme was accompanied by positive evidence of Congress's and HUD's presumption that private remedies would be available under the USHA. ${ }^{123}$ For the Court, these

117. Id. at $770-74$.

118. Id. at $770,774-75$.

119. The Wright Court stated:

[Section] 1983 provides a remedial cause of action unless the state actor demonstrates by express provision or other specific evidence from the statute itself that Congress intended to foreclose such private enforcement. "We do not lightly conclude that Congress intended to preclude reliance on $\S 1983$ as a remedy" for the deprivation of a federally secured right.

Id. at 771 (emphasis added) (quoting Smith v. Robinson, 468 U.S. 992, 1012 (1984)).

120. Id. at 771 ("We are unconvinced ... that respondent has overcome its burden of showing that 'the remedial devices provided in [the Housing Act] are sufficiently comprehensive ... to demonstrate congressional intent to preclude the remedy of suits under $\S 1983$.' " (quoting Middlesex County Sewerage Auth. v. National Sea Clammers Ass'n, 453 U.S. 1, 20 (1981))).

121. Id. at 773 .

122. Id. The Court referred to the local administrative grievance procedure mandated by a 1985 amendment to the statute, 42 U.S.C. $\S 1437 \mathrm{~d}(\mathrm{k})$ (Supp. III 1985), and implemented by a series of HUD regulations, 24 C.F.R. $\S \S 966.50-966.59$ (1987). See 107 S. Ct. at 773-74 \& nn. 8 \& 11 ; see also supra notes $82-86$ and accompanying text.

123. The Court stated:

Not only are the Brooke Amendment and its legislative history devoid of any express indication that exclusive enforcement authority was vested in HUD, but there have also been both congressional and agency actions indicating that enforcement authority is not centralized and that private actions were anticipated. Neither, in our view, are the remedial mechanisms provided sufficiently comprehensive and effective to raise a clear inference that Congress intended to foreclose a $\$ 1983$ cause of action for the enforcement of tenants' rights secured by federal law.

$107 \mathrm{~S}$. Ct. at 771. The Court proceeded to cite a number of examples of "congressional and agency actions" that appeared to show that Congress contemplated the availability of private enforcement 
findings distinguished the USHA and the Brooke Amendment from the statutes at issue in Middlesex and Smith. The findings also dispensed with the preclusion problem and raised an inference of congressional intent to permit private enforcement of the USHA via section 1983 actions. ${ }^{124}$

The Court then turned to an analysis of whether, under the Pennhurst test, ${ }^{125}$ the USHA creates substantive rights in tenants. ${ }^{126}$ The Court perfunctorily dismissed the claim that the USHA and the Brooke Amendment were too vague and indefinite to create enforceable rights. "The Brooke Amendment could not be clearer ... . [It] was a mandatory limitation focusing on the individual family and its income. The intent to benefit tenants is undeniable." 127 Because the USHA thus created enforceable rights, and because there was no evidence of congressional intent to foreclose section 1983 enforcement actions, the Court reversed the judgment below and held that tenants could bring section 1983 actions against local housing authorities. ${ }^{128}$

under the USHA. The Court noted, for example, that in raising the Brooke Amendment's rent ceiling from 25 to $30 \%$, Congress specifically exempted the five-year phase-in of rent increases by the Secretary of HUD from judicial review. Id. at 771. The Court further noted that, "[a]pparently dissatisfied with even a temporary preclusion of judicial review, Congress repealed it two years later." Id. at 772.

The Court also noted that the grievance procedure mandated by the USHA, 42 U.S.C. $\S 1437 d(k)$ (1982 \& Supp. III 1985), was intentionally informal and noncomprehensive. "Congress" aim was to provide a 'decentralized, informal, and relatively non-adversarial administrative process' for resolving tenant-management disputes." $107 \mathrm{~S}$. Ct. at 772 (quoting Samuels v. District of Columbia, 770 F.2d 184, 189 (D.C. Cir. 1985)). The grievance procedure was not available to resolve possible class actions. Id. Moreover,

HUD itself has never provided a procedure by which tenants could complain to it about the alleged failures of [public housing authorities] to abide by their annual contributions contracts, the Brooke Amendment or HUD regulations; nor has it taken unto itself the task of reviewing [public housing authority] grievance procedure decisions.

Id. (emphasis added). Perhaps most importantly, the grievance procedure regulations themselves appear to contemplate private judicial remedies,

provid[ing] that a decision terminating a grievance proceeding shall in no way effect [sic] the rights of a tenant either to seek "trial de novo or judicial review in any judicial proceedings, which may thereafter be brought in the matter." HUD thus had no thought that its own supervisory powers or the grievance system that it had established foreclosed resort to the courts by tenants who claimed that a [public housing authority] PHA was not observing the commands of the Brooke Amendment.

Id. (quoting 24 C.F.R. $\$ 966.57$ (c) (1986)). On the scope and adequacy of the USHA local grievance procedure, see also supra notes $82-86$ and accompanying text.

124. $107 \mathrm{~S}$. Ct. at $772-74$.

125. See supra notes $105-06$ and accompanying text.

126. $107 \mathrm{~S} . \mathrm{Ct}$. at 774 .

127. Id. (emphasis added).

128. Id. at 775. 


\section{Wright, Section 1983 Enforcement and Implied Private Rights of Action.}

As the preceding discussion illustrates, the prevailing standards for implication of a private right of action ${ }^{129}$ and section 1983 enforcement ${ }^{130}$ under a federal statute are substantively distinct. Nevertheless, the standards for section 1983 enforcement and the implication of private rights of action are sufficiently similar to have produced substantial scholarly criticism ${ }^{131}$ and considerable confusion in the lower federal courts-especially those that have dealt with questions of private enforcement under the USHA. ${ }^{132}$ Judge Gordon, concurring in the Fourth Circuit opinion in Wright, noted that "the proper $\S 1983$ analysis has become mistakenly entangled with the analysis for an implied private right of action."133

The confusion is understandable, given the convergence of several of the applicable standards for respective analysis of section 1983 and implied right of action issues. For example, section 1983 problems require examination of whether Congress expressly or impliedly foreclosed section 1983 actions; ${ }^{134}$ in a related fashion, an implied right of action problem requires the determination of whether Congress contemplated private enforcement, as a general matter, of the statute at issue. Under Middlesex, a section 1983 issue requires an examination of the "remedial scheme" of the statute. ${ }^{135}$ Likewise, the parallel third prong of the Cort test compels the court to examme the "statutory scheme" of the statute. ${ }^{136}$ Under Pennhurst, section 1983 problems require analysis of whether "enforceable rights" are created by the statute; 137 similarly, the first prong of the Cort test focuses on the right- and benefit-conferring elements of the statute under which a plaintiff claims an implied private

129. See supra notes $17-36$ and accompanying text.

130. See supra notes $101-08$ and accompanying text.

131. See generally Brown, Whither Thiboutot: Section 1983, Private Enforcement, and the Damages Dilemma, 33 DEPAul L. REv. 31 (1983); Sunstein, Section 1983 and the Private Enforcement of Federal Law, 49 U. CH1. L. REv. 394 (1982); Wartelle \& Louden, Private Enforcement of Federal Statutes: The Role of the Section 1983 Remedy, 9 HASTINGs ConsT. L.Q. 487 (1982); Note, Implied Private Rights of Action and Section 1983: Congressional Intent Through a Glass Darkly, 23 B.C.L. REV. 1439 (1982); Note, Preclusion of Section 1983 Causes of Action by Comprehensive Statutory Remedial Schemes, 82 Colum. L. REv. 1183 (1982).

132. See supra note 44 and accompanying text.

133. Wright v. City of Roanoke Redev. \& Hous. Auth., 771 F.2d 833, 838 (4th Cir. 1985) (Gordon, J., concurring), rev'd, 107 S. Ct. 766 (1987).

134. Middlesex County Sewerage Auth. v. National Sea Clammers Ass'n, 453 U.S. 1, 13-21 (1981).

135. Id. at 14-15.

136. Cort v. Ash, 422 U.S. 66, 78 (1975).

137. Pennhurst State School \& Hosp. v. Halderman, 451 U.S. 1, 18-19 (1981). 
right of action. ${ }^{138}$

The distinctions in the analysis of section 1983 and implied right of action problems lie largely in the varying strengths of relevant presumptions about congressional intent and the different levels of inquiry into the indicia of that intent. In the absence of circumstances triggering either the Middlesex or Pennhurst exceptions, section 1983 actions to enforce federal statutes are presumptively permissible; ${ }^{139}$ under Cort, however, a court will imply a private right of action only when extensive analysis of congressional intent and the statutory scheme reveals that Congress expressly or impliedly contemplated private enforcement. 140

The Wright Court failed to clarify the confusion surrounding these subtle distinctions. ${ }^{141}$ Nonetheless, the Court's analysis parallels that which it might have undertaken in examining an USHA implied right of action problem. The Wright Court spoke to the central issue under the first prong of the Cort v. Ash test in conjuction with its Pennhurst analysis of whether the USHA creates enforceable rights in tenants. ${ }^{142}$ The Court held that, under the USHA, "[t] $]$ he intent to benefit tenants is undeniable," and that "the benefits Congress intended to confer on tenants are sufficiently specific and definite to qualify as enforceable rights." 143 These findings clearly satisfy the threshold Cort test: the statute under which an implied private right of action is claimed must confer enforcea-

138. Cort, 422 U.S. at 78.

139. See supra notes $105-08$ and accompanying text.

140. See supra notes 17-36 and accompanying text.

141. The Court may have been influenced by the petitioners' particular emphasis on the divergence of section 1983 and implied riglit of action problems, and their accompanying insistence that Wright presented a section 1983 issue alone. Brief for Petitioners at 27-34, Wright v. City of Roanoke Redev. \& Hous. Auth., 107 S. Ct. 766 (1987) (No. 85-5915).

Nonetheless, the Wright Court's exacerbation of the difficulties associated with the confluence of the Cort and Thiboutot-Middlesex-Pennhurst tests resulted in a flawed tendency on the part of the lower courts to treat distinct elements of the Supreme Court's section 1983 and implied right of action doctrines as substantively identical. The United States Court of Appeals for the District of Columbia Circuit, for example, recently stated that the Pennhurst analysis of whether a particular federal statute creates enforceable rights in fact "comprises the first of [the] four factors used to determine whether to imply a cause of action from a federal statute." Edwards v. District of Columbia, 821 F.2d 651, 654 n.4 (D.C. Cir. 1987) (citing Cort v. Ash, 422 U.S. 66, 78 (1975)).

While the section 1983 private enforccment inquiry of whether a federal statute creates an "enforceable right" is closely related to the Cort test's initial inquiry of whether the plaintiffs are members of a protected class, the tests are substantively distinct. Indeed, it might be argued that the latter test is easier to meet. A particular plaintiff might successfully show that a given federal statute clearly is intended to benefit a certain class of citizens (of which he is a member), without necessarily also showing that the statute is sufficiently specific so as to create an "enforceable right" in that class within the meaning of Pennhurst. This distinction renders the Wright Court's failure to hold that an implied private right of action exists to enforce provisions of the USHA even less understandable. See infra notes 142-61 and accompanying text.

142. See supra note 20 and accompanying text.

143. $107 \mathrm{~S}$. Ct. at $\mathbf{7 7 4 - 7 5}$. 
ble rights on the prospective plaintiffs. Thus as an initial matter, the Wright Court's analysis resembles the Cort test, despite the fact that the implied right of action issue was not explicitly discussed.

Likewise, and more important, the Court's analysis under Middlesex of the section 1983 congressional intent issue appears to satisfy the second and third prongs of the Cort test. ${ }^{144}$ The Court found not only that Congress had not intended to preclude section 1983 actions to enforce the USHA, but also that the legislature affirmatively meant to permit "private enforcement." 145 The key for the present implied right of action analysis hes in the Court's willingness to go beyond the level of inquiry into legislative intent required under Middlesex and Smith. The Middlesex-Smith presumption of no intent to preclude section 1983 actions would have been triggered by a simple finding that, in enacting the USHA, Congress failed to address the section 1983 question. ${ }^{146}$ Yet the Court went further, finding affirmative evidence that, as a general matter, "private actions were anticipated" by Congress. ${ }^{147}$

This additional, facially unnecessary analysis would satisfy the Cort requirement that a court find positive evidence of explicit or implicit congressional contemplation of private enforcement before implying a private right of action. The Court's evidence is framed in terms that are similar to those used in the application of Cort; the Court extensively discussed indicia of legislative intent drawn from both the statute's legislative history and the statutory scheme of enforcement. ${ }^{148}$ By discussing congressional intent as to private enforcement generally rather than as to section 1983 enforcement alone, the Wright Court included its section 1983 analysis within a de facto, unstated implied right of action discussion. The Court went further than necessary, indirectly highlighting the differences in the respective section 1983 and implied right of action standards. Rather than clarifying the issue, however, the Court inexplicably left the USHA private enforceinent issue unsettled and further confused. ${ }^{149}$

144. See supra note 20 and accompanying text.

145. See supra notes $116-24$ and accompanying text.

146. See supra notes $118-20$ and accompanying text.

147. $107 \mathrm{~S}$. Ct. at 771 .

148. Id. at 771-75; see also supra notes 119-24 and accompanying text.

149. The Wright Court may have failed to reach the USHA implied right of action question, notwithstanding the discussion of implied private actions in the lower court opinions, because its holding on the section 1983 question made further analysis unnecessary. Indeed, the petitioners in Wright argued for such an approach. See supra note 141. Perhaps more significantly, the Wright majority may have found it far less insurmountable a task to justify private enforcement of the Brooke Amendment via section 1983 actions than through implied private rights of action. The United States Court of Appeals for the District of Columbia Circuit, in an opinion issued less than 


\section{Post-Wright Uncertainty About Private Enforcement.}

The Wright Court left open two essential questions: first, which provisions of the USHA other than the Brooke Amendment may be "privately enforced"; and second, which methods of private enforcementviz., implied private rights of action, section 1983 actions or third-party beneficiary actions in contract-are available to plaintiffs seeking enforcement of USHA provisions. Since the Supreme Court decided Wright, several lower federal courts have wrestled with both questions with considerably less success than might have been expected had the Wright decision more completely analyzed the salient USHA private enforcement issues.

In Edwards v. District of Columbia, ${ }^{150}$ the United States Court of Appeals for the District of Colunbia Circuit engaged in the most exhaustive post-Wright discussion of the USHA private enforcement question. Edwards considered a suit brought by residents of an USHA-assisted housing project in the District of Columbia against the District (as the tenants' landlord) and HUD, alleging that the District's failure to keep the project in a decent, safe and sanitary condition resulted in its "constructive demolition," in violation of 42 U.S.C. section 1437p. ${ }^{151}$ Under section 1437p, HUD may not approve a local housing authority's application for the demolition of an USHA-assisted project unless the applying public housing authority has shown, inter alia, that the housing units in question are unusable, that it is not reasonable to restore the units,

six months after Wright was decided, explicitly recognized the greater ease with which plaintiffs can establish a section 1983 cause of action:

Whereas in implied cause of action cases plaintiffs must demonstrate both that the relevant federal law secures rights and that Congress intended to create a cause of action to enforce those rights, in $\S 1983$ cases plaintiffs need only show that the statute in question indeed secures the appropriate rights.

Edwards v. District of Columbia, 821 F.2d 651,660 n.11 (D.C. Cir. 1987). This note takes issue with the Edwards court's assertion, implied in the quoted language, that the establishment of an implied right of action requires affirmative evidence of congressional intent to permit private enforcement. See supra notes $28 \& 31$. The Edwards court clearly recognized, however, that section 1983 analysis does not require an exhaustive search for congressional contemplation of and assent to private enforcement actions. Rather, Thiboutot, Pennhurst and Middlesex, read together, establish a presumption in favor of the availability of section 1983 actions in the face of congressional silence on the private enforcement question. See supra note 119 and accompanying text.

The Wright Court may have understood the distinctions, recognized in Edwards, between section 1983 and implied private right of action questions. If so, however, it is even more difficult to understand, given the breadth of its findings on the preclusion and enforceable rights questions, why the Court failed to hold explicitly that an implied right of action exists for the enforcement of specific USHA provisions. While the Wright Court clearly opened the door to such a holding in the future, an entire class of plaintiffs-namely those seeking relief from defendants other than state actorshave been left unsure of the viability of private enforcenent of the USHA.

150. 821 F.2d 651 (D.C. Cir. 1987).

151. Id. at 653 . 
that the demolition application has been developed in consultation with the affected tenants, and that the public housing authority has assisted tenants in securing comparable affordable housing. ${ }^{152}$

The Edwards court held that a section 1983 action was not available for the private enforcement of section $1437 \mathrm{p} .{ }^{153}$ The court began with a statement of its reading of the relevant precedents:

We ... read Pennhurst and Wright together as standing for the proposition that Congress must employ "sufficiently specific and definite" statutory language in order to create rights and, at the same time, give notice to the relevant governmental unit of its obligations in relation to such rights. The issue to be decided im each case, of course, is whether the statute is in fact "sufficiently specific and definite" so as to create the rights alleged by the plaintiffs .... ${ }^{154}$

On the dispositive question, the Court held that "neither the language nor the legislative history of $\S 1437 p$ creates rights im public housing tenants against the constructive demolition of their units."15s Writing for the majority, Chief Judge Wald argued that while section $1437 p$ inposed an affirmative duty on HUD to approve or reject a demolition application in light of certain statutory criteria, it imposed no affirmative duty on local housing authorities to keep project buildings in decent, safe and sanitary condition and thus created no rights on behalf of the tenant-plaintiffs.

Section $1437 p$ as written ... does not establish independent duties on the part of the PHAs [local housing authorities]; instead, it creates conditions precedent that must occur before the Secretary approves a demolition application (and, necessarily, before actual demnolition). As in contract law, these conditions precedent do not, by themselves, constitute independent duties. ${ }^{156}$

At least one other federal court has rejected a claim for private enforcement of USHA provisions. In Price v. Pierce, 157 the United States Court of Appeals for the Seventh Circuit held that prospective tenants of USHA-assisted housing projects are not third-party beneficiaries of Annual Contributions Contracts between HUD and local housing authorities and thus cannot maintain claims for private enforcement of tenant selection provisions in those contracts.

152. See 42 U.S.C. § 1437p (1982 \& Supp. III 1985); 24 C.F.R. pt. 970 (1987) (implementing regulations for section $1437 \mathrm{p})$.

153. 821 F.2d at 661 .

154. Id. at 657-58.

155. Id. at $659-60$.

156. Id. at 659 .

157. 823 F.2d 1114, 1121-22 (7th Cir. 1987), petition for cert. filed, 56 U.S.L.W. 3438 (U.S. Jan. 5, 1988) (no. 87-967); see also Gholston v. Housing Auth., 818 F.2d 776, 780-81 (11th Cir. 1987) (noting that while section 1983 action appeared to be available for enforcement of admissions provisions of USHA, question was not raised on appeal and was unnecessary to decision of case). 
The lower federal courts would not have to wrestle with the myriad of USHA private enforcement questions if the Wright Court had simply concluded, as its own analysis suggested, that an implied private right of action exists to enforce provisions of a statute clearly designed to benefit a discrete class of citizens. Instead, the Wright holding has forced courts, like the panel in Edwards, to conduct a complex (and often highly semantic) analysis of whether each individual USHA provision creates an enforceable right such that a section 1983 claim is available. Plaintiffs have likewise been forced to rely on alternative theories, including thirdparty beneficiary claims, in order to state a claim for rehief-most notably against HUD, which as a federal agency does not come within the state action language of section 1983. ${ }^{158}$ In this sense, the post-Wright decisions are the most compelling illustration of the confused consequences of the Supreme Court's failure explicitly to adopt the result most consistent with its own analysis.

\section{E. The Consequences of Wright.}

Although the Court repeatedly has voiced reluctance to decide more than is necessary for the disposition of a given case, ${ }^{159}$ the Wright Court's analysis and findings could as easily have led it to find that an implied right of action exists under the USHA. The Court's conclusions on the questions of congressional intent, the USHA enforcement scheme, and the rights-conferring character of the statute address and satisfy the Cort implied right of action test. At bare minimum, the Court might have waited for a case more akin to Howard v. Pierce, ${ }^{160}$ which squarely presented the salient USHA private enforcement issues, and would have presented an opportunity to clarify those issues in particular and, perhaps, the doctrine of implied rights of action in general.

Instead, the Court's decision in Wright leaves a number of answerable questions unanswered. By validating section 1983 actions alone, the Court left hanging the class of plaintiffs who, like the plaintiffs in Howard, seek to proceed against HUD (rather than a local housing authority) ${ }^{161}$ and who thus cannot take advantage of a section 1983 action. It is still uncertain whether these plaintiffs can maintain a private right of action under the USHA. More important, the Court clouded its own section 1983 and implied right of action doctrines by creating the impression that the standards for private enforcement of a federal statute under

158. See, e.g., Price, 823 F.2d at 1121; Edwards, 821 F.2d at 661-62.

159. See supra note 141 .

160. 738 F.2d 722 (6th Cir. 1984); see supra note 37 and accompanying text.

161. Id. 
either approach are at best hopelessly entangled or at worst substantively indistinguishable.

Wright is thus a decision that paradoxically goes too far in its analysis, but not far enough in its result. The far better approach would have been for the Court, in Wright or some later case, to meet the broader implied right of action question head on and obviate the need for section 1983 analysis. Because the fundamental issue is neither implied rights of action nor section 1983 enforcement, but more generally private enforcement of the USHA, Wright iguores the significant legal questions in this area and instead leaves an entire class of plaintiffs in limbo, further confusing an already complex field of federal courts practice. Indeed, the only prudent way for the Court to resolve the real issue in a consistent manner is to recognize the implied right of action under the USHA which, as the Wright Court's own analysis makes clear, undeniably exists.

\section{CONCLUSION}

Despite the Supreme Court's increasingly restrictive standards, a private right of action should be implied under the United States Housing Act of 1937. Examination of the statute, its scheme of enforcement and its legislative history reveals that the USHA meets the requirements of the four-part test announced in Cort v. Ash, and that implication of a private right of action under the statute would therefore further congressional intent and be "consistent with the underlying purposes of the legislative scheme"162 - namely, to remedy "the acute shortage of decent, safe, and sanitary dwellings for families of lower income."163

The Supreme Court, however, unnecessarily complicated the issue of private enforcement of the USHA in Wright $v$. Roanoke Redevelopment \& Housing Authority. By overextending its analysis of whether plaintiffs may maintain section 1983 actions to redress alleged violations of the USHA, the Court muddled both its implied private right of action and section 1983 enforcement doctrines, while leaving the fundamental USHA private enforcement question unanswered. Until the Court clarifies both the narrow USHA private enforcement issue and the broader implied right of action and section 1983 doctrines, the lower federal courts should still reach the conclusion that logically follows from the

162. Cort v. Ash, 422 U.S. 66, 78 (1975).

163. 42 U.S.C. $\S 1437$ (1982). 
prevailing law: an implied right of action exists to allow private plaintiffs to enforce provisions of the United States Housing Act.

Paul E. Harner 